\title{
The relationship between aortic calcification on chest radiograph and neurocognitive impairment after coronary artery bypass grafting
}

\author{
Göğüs grafisinde aort kalsifikasyonu ve koroner arter baypas greftleme sonrası \\ nörokognitif bozulma arasındaki ilişkisi
}

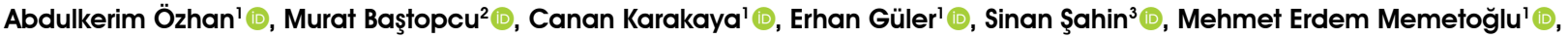 \\ Bülend Ketenci' ${ }^{10}$, Mahmut Murat Demirtaş ${ }^{1}$ (i) \\ Institution where the research was done: \\ Dr. Siyami Ersek Thoracic and Cardiovascular Surgery Training and Research Hospital, istanbul, Turkey
}

\author{
Author Affiliations: \\ 'Department of Cardiovascular Surgery, Dr. Siyami Ersek Thoracic and Cardiovascular Surgery Training and Research Hospital, istanbul, Turkey \\ 2Department of Cardiovascular Surgery, Tatvan State Hospital, Bitlis, Turkey \\ ${ }^{3}$ Department of Radiology, Dr. Siyami Ersek Thoracic and Cardiovascular Surgery Training and Research Hospital, Istanbul, Turkey
}

\begin{abstract}
Background: In this study, we aimed to investigate the possible relationship between aortic calcification as detected by preoperative chest radiography and postoperative neurocognitive impairment in patients undergoing coronary artery bypass grafting.

Methods: A total of 124 patients (101 males, 23 females; mean age: $59.9 \pm 8.8$ years; range, 34 to 84 years) who underwent coronary artery bypass grafting in our clinic between January 2019 and July 2019 were included. Of these patients, 35 whose preoperative chest radiography revealed aortic calcification in the aortic knuckle were included as the patient group. The control group consisted of 89 patients without aortic calcification. The patients with aortic calcification underwent additional imaging with thoracic computed tomography angiography and ascending aorta and aortic arch calcium scores were calculated. Neurocognitive dysfunction was assessed using the Standardized Mini-Mental State Examination. Postoperative delirium was evaluated by confusion assessment method in the intensive care unit. Both groups were compared for demographic, operative and postoperative data.
\end{abstract}

Results: Of all patients included in the study, the overall cerebrovascular event incidence was $3.2 \%$. Although not statistically significant, the number of patients with neurocognitive decline was higher in the patient group than the control group ( $48.6 \%$ vs. $34.8 \%$, respectively; $\mathrm{p}=0.157)$. Both Standardized Mini-Mental State Examination score decline and percentage decline were significantly higher in the patients with high aortic arch calcium scores $(>2,250 \mathrm{AU})$. Carotid artery stenosis was 3.2 times higher in the patient group. In the patients with carotid artery stenosis, the aortic arch calcium scores were also higher $(\mathrm{p}=0.042)$.

Conclusion: Aortic calcification detectable on chest radiography with high calcium scores may be associated with neurocognitive impairment and carotid artery stenosis in patients undergoing coronary artery bypass grafting.

Keywords: Aortic calcification, cardiac surgery, chest radiography, neurocognitive dysfunction.
$\ddot{O} Z$

Amaç: Bu çalışmada, koroner arter baypas greftleme yapılan hastalarda ameliyat öncesi göğus grafisi ile tespit edilen aort kalsifikasyonu ile ameliyat sonrası nörokognitif bozulma arasındaki olası ilişki araştırıldı.

Çalışma planı: Ocak 2019 - Temmuz 2019 tarihleri arasında kliniğimizde koroner arter baypas greftleme yapilan toplam 124 hasta (101 erkek, 23 kadın; ort. yaş: $59.9 \pm 8.8$ yıl; dağılım, 34-84 yıl) çalışmaya alındı. Bu hastaların ameliyat öncesi çekilen göğüs grafisinde aort topuzu üzerinde aort kalsifikasyonu olan 35'i hasta grubunu oluşturdu. Aort kalsifikasyonu olmayan 89 hasta ise kontrol grubunu oluşturdu. Aort kalsifikasyonu saptanan hastalara ayrıca bilgisayarlı tomografi anjiyografi uygulandı ve çıkan aort ve arkus aorta kalsiyum skorları hesaplandı. Nörokognitif disfonksiyon, Standardize Mini Mental Test ile değerlendirildi. Ameliyat sonrası deliryum, yoğun bakım ünitesinde konfüzyon değerlendirme testi ile değerlendirildi. Gruplar demografik, ameliyat ve ameliyat sonrası verilere göre karşılaştırıldı.

Bulgular: Çalışmaya alınan tüm hastalar arasında, genel serebrovasküler olay insidansı \%3.2 idi. İstatistiksel olarak anlamlı olmamakla birlikte, nörokognitif gerileme olan hasta sayısı, kontrol grubuna kiyasla, hasta grubunda daha yüksek idi (sırasıyla \%48.6 ve \%34.8; p=0.157). Yüksek arkus aorta kalsiyum skorlu ( $>2250$ AU) hastalarda Standardize Mini Mental Test skor düşüşü ve düşüş yüzdesi anlamlı olarak daha yüksek idi. Karotis arter darlığ 1 , hasta grubunda 3.2 kat daha yüksekti. Karotis arter darlığ 1 saptanan hastalarda, arkus aorta kalsiyum skoru da daha yüksek idi $(\mathrm{p}=0.042)$.

Sonuç: Yüksek kalsiyum skorları ile birlikte göğüs grafisinde tespit edilen aort kalsifikasyonu, koroner arter baypas greftleme yapılan hastalarda nörokognitif bozulma ve karotis arter darlı̆̆ı ile ilişkili olabilir.

Anahtar sözcükler: Aort kalsifikasyonu, kalp cerrahisi, akciğer grafisi, nörokognitif disfonksiyon.

Received: December 17, 2020 Accepted: March 04, 2021 Published online: April 26, 2021

Correspondence: Abdulkerim Özhan, MD. Dr. Siyami Ersek Göğüs Kalp ve Damar Cerrahisi Eğitim ve Araştırma Hastanesi, Kalp ve Damar Cerrahisi Kliniği, 34668 Üsküdar, İstanbul, Türkiye. Tel: +90 216-5424444 e-mail: draozhan@gmail.com 
Coronary artery bypass grafting (CABG) can be performed with acceptable mortality and morbidity rates in the current era. Despite advances in preoperative imaging and increased surgical experience, the operative technique inherently brings along inevitable complications. Neurological and neurocognitive impairments are among the most serious of these complications..$^{[1-3]}$

Postoperative neurocognitive dysfunction (POND), characterized by impaired attention, concentration, and memory with possible long-term effects, frequently occurs following CABG. ${ }^{[4]}$ Three main mechanisms are held responsible for POND: microembolism, insufficient cerebral perfusion, and systemic inflammatory response..$^{[3,5]}$ The CABG patients are often accompanied by advanced age, carotid artery stenosis, and diabetes mellitus (DM), which may all increase the risk of POND. The incidence of POND in the early postoperative period after CABG varies between 20 and $50 \% .{ }^{[4]}$

Aortic calcification (AC) is an advanced complication of atherosclerosis that stems from atheroma plaques. In patients with $\mathrm{AC}$, aortic manipulation, aortic cross-clamping, and mobilization of atheromatous debris in the ascending aorta by jet flow at the beginning of cardiopulmonary bypass (CPB) cause microembolizations. ${ }^{[5]}$ Severe AC can be seen in $2 \%$ of cardiac surgery patients and this rate can be as high as $30 \%$ with the increased age. ${ }^{[6]}$

Detection of $\mathrm{AC}$ is possible on posteroanterior chest radiography $(\mathrm{CR})$, which is a routine preoperative study of CABG patients. ${ }^{[7]}$ Computed tomography (CT) of patients with AC can reveal the localization, structure, and calcium density of $\mathrm{AC}$ and, thus, may help to predict the risk of POND and to reduce the risk by optimal surgical planning. In the present study, we aimed to investigate the association between AC detected on preoperative $\mathrm{CR}$ and POND in patients undergoing elective $\mathrm{CABG}$.

\section{PATIENTS AND METHODS}

This single-center, prospective, case-control study was conducted at Dr. Siyami Ersek Thoracic and Cardiovascular Surgery Training and Research Hospital, Department of Cardiovascular Surgery between January 2019 and July 2019. The patients over 18 years of age who underwent isolated on-pump CABG were included in the study. Of 750 patients who underwent open heart surgery throughout the study period, 124 (101 males, 23 females; mean age: $59.9 \pm 8.8$ years; range, 34 to 84 years) who met the inclusion criteria were screened. Among 124 patients,
35 whose $\mathrm{CR}$ revealed $\mathrm{AC}$ in the aortic knuckle were included as the patient group. The control group consisted of 89 patients without AC. Patients who had neuropsychiatric diseases such as psychosis, dementia, and mental retardation that could affect psychometric analysis and neurocognitive functions, previous cerebrovascular accident (CVA), illiteracy, visual and hearing impairment, underwent emergent CABG, had moderate and severe valvular disease, intracardiac thrombus, preoperative atrial fibrillation (AF) and flutter, underwent off-pump CABG, and previous open heart surgery were excluded from the study. A written informed consent was obtained from each patient. The study protocol was approved by the Haydarpaşa Numune Training and Research Hospital Clinical Research Ethics Committee (HNEAK-KAEK-2018/9). The study was conducted in accordance with the principles of the Declaration of Helsinki.

\section{Definitions}

Hypertension was defined as a systolic or diastolic pressure of $\geq 140$ or $\geq 90 \mathrm{mmHg}$, respectively. Diabetes mellitus was defined as a fasting glucose level greater than $126 \mathrm{mg} / \mathrm{dL}$ or the use of insulin, antidiabetic agents. Hyperlipidemia was defined as a serum total cholesterol of $\geq 240 \mathrm{mg} / \mathrm{dL}$, serum triglyceride of $\geq 200 \mathrm{mg} / \mathrm{dL}$, or low-density lipoprotein cholesterol of $\geq 130 \mathrm{mg} / \mathrm{dL}$.

Glomerular filtration rate (GFR) was calculated using the Chronic Kidney Disease Epidemiology

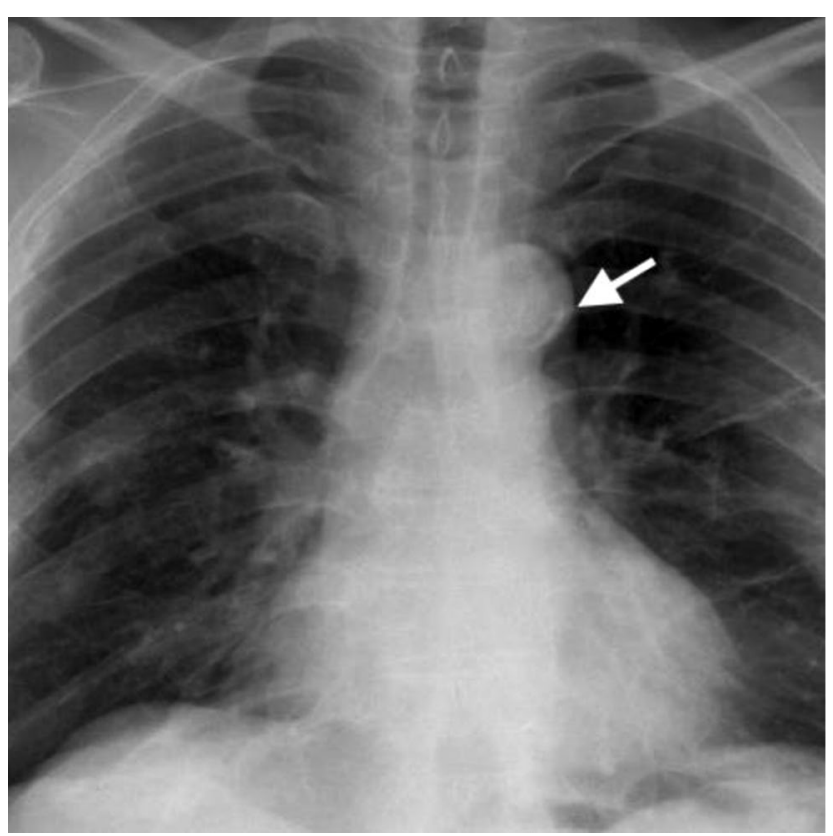

Figure 1. Appearance of aortic calcification at aortic knuckle on chest radiograph. 


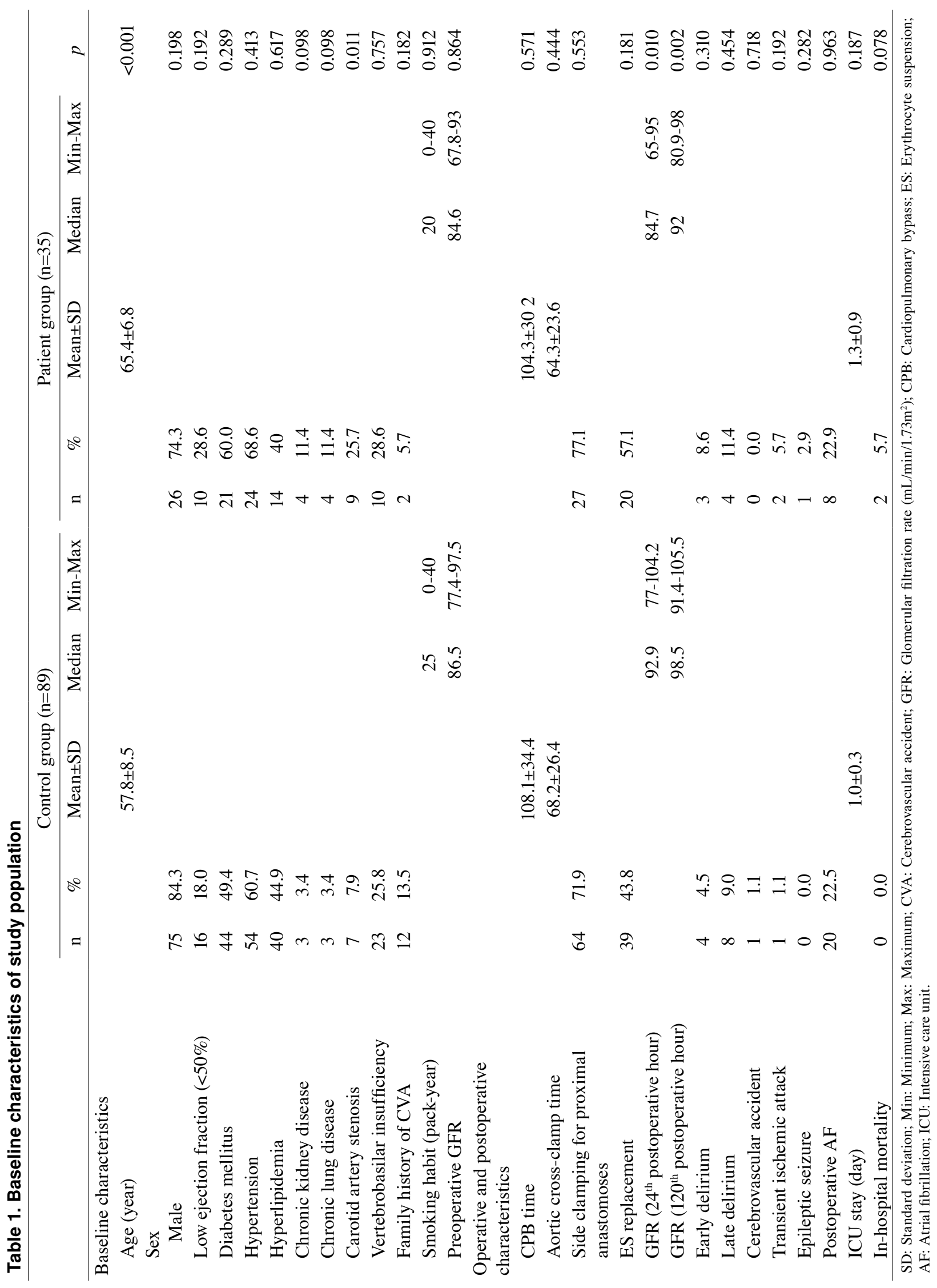


Table 2. Aortic calcification scores according to the presence of carotid artery stenosis

\begin{tabular}{lccccccc}
\hline & \multicolumn{2}{c}{ Carotid artery stenosis $(\mathrm{n}=26)$} & & \multicolumn{2}{c}{ Carotid artery stenosis $(\mathrm{n}=9)$} \\
& \multicolumn{2}{c}{ No } & & & \multicolumn{2}{c}{ Yes } & \\
\cline { 2 - 3 } & Median & Min-Max & & Median & Min-Max & $p$ \\
\hline Ascending aorta CS & 137 & $20-311$ & & 103 & $0-655$ & 0.909 \\
Aortic arch CS & 912 & $258-1557$ & & 1611 & $915-2957$ & 0.042 \\
Total aortic CS & 1179 & $498-2015$ & & 2246 & $1057-3904$ & 0.089 \\
\hline
\end{tabular}

Collaboration (CKD-EPI) equation. Carotid artery stenosis and vertebrobasilar insufficiency were assessed with preoperative Duplex ultrasound. A significant carotid artery lesion was defined as $\geq 50 \%$ stenosis. Bilateral vertebral artery flow less than $200 \mathrm{~mL} / \mathrm{min}$ was accepted as vertebrobasilar insufficiency. The most recent values before surgery were taken into account for laboratory values.

\section{Assessment of AC}

All CRs were evaluated by at least two specialists from the radiology and cardiovascular surgery departments. As defined by Hashimoto et al., ${ }^{[7]}$ patients with $\mathrm{AC}$ in the aortic knuckle seen on $\mathrm{CR}$ were included in the patient group and those without AC were included in the control group (Figure 1).

All patients in the patient group underwent non-contrast thoracic CT angiography (Toshiba, Aquillion $64 \mathrm{CT}$ ) with 3-mm slices. The calcific lesion was defined as an increase of $\geq 130$ Hounsfield units (HU) in three consecutive pixels. Aortic calcification on CT scan was defined as any calcific lesion in the ascending and/or aortic arch. Ascending aorta calcium score (CS) and aortic arch CS were calculated using the method described by Agatston et al., ${ }^{[8]}$ using semi-automatic Vitrea ${ }^{\circledR} 2.0$ (Vital Images, Minnetonka, $\mathrm{MN}$ ) imaging software. The total aortic CS was calculated as the sum of ascending aorta and aortic arch CSs. High ascending aorta and aortic arch CSs were defined as $\mathrm{CS} \geq 2,250$ Agatston units (AU). ${ }^{[9]}$

\section{Surgical procedure}

General anesthesia was induced with propofol, fentanyl, and rocuronium bromide. The CPB was achieved by cannulation of the ascending aorta and two-stage right atrial venous cannulation. Aortic cross-clamp was applied. Cardiac arrest was achieved by antegrade hypothermic blood cardioplegia and the patients were cooled down to a body core temperature of $32^{\circ} \mathrm{C}$. After completion of distal anastomoses, the aortic clamp technique for proximal anastomoses (cross or lateral) was decided by the surgeon according to the extent of $\mathrm{AC}$.

\section{Assessment of neurological impairment}

Neurological examination was done in the pre- and postoperative periods. Neurological deficits such as paresis, plegia, aphasia, epileptic attack, and transient ischemic attack were recorded, and ischemic areas were evaluated by cranial $\mathrm{CT}$ and/or magnetic resonance imaging (MRI).

Postoperative delirium was evaluated at $24 \mathrm{~h}$ using the Confusion Assessment Method in Intensive Care Unit (CAM-ICU) test and defined as early-stage delirium. ${ }^{[10,11]}$ Delirium emerging with $\geq 24 \mathrm{~h}$ of ICU stay or recurrent ICU admission were evaluated daily by the CAM-ICU test and defined as late-stage delirium.

We used the Standardized Mini-Mental State Examination (SMMSE) to assess postoperative neurocognitive impairment. The primary endpoints of the study were the SMMSE score decline and percentage decline. Secondary endpoints were the presence of delirium, and major cerebrovascular events. The SMMSE consists of several sections that evaluate orientation, recording memory, attention and calculation, recall, and language skills. Patients answer questions scored between 0 and $30 .^{[12,13]}$

The SMMSE was conducted on the day before surgery and on postoperative Days 5-7 under appropriate communication conditions. The preoperative test result was accepted as the baseline value of the patient. Both pre- and postoperative SMMSE scores were compared, and score decline and percentage decline at the SMMSE scores were calculated. It was assumed that the patients with an increase in the postoperative SMMSE scores compared to the preoperative scores were not affected by surgery in terms of neurocognition, and positive 
SMMSE score changes were defaulted to zero. Both groups were compared for changes in the SMMSE scores and other perioperative factors which affect neurocognitive function.

\section{Statistical analysis}

Statistical analysis was performed using the IBM SPSS version 22.0 software (IBM Corp., Armonk, NY, USA). To test for normality, the Shapiro-Wilks test was used. Nominal variables were expressed in number and percentage, while normally distributed continuous variables were expressed in mean \pm standard deviation (SD) and non-normally distributed continuous variables in median (interquartile range [IQR]). The chi-square test was used for nominal values in comparison of the groups, the Fisher exact chi-square test in case of expected frequencies below 5, the independent samples t-test for comparison of parametric data, and the Mann-Whitney $U$ test for comparison of non-parametric data. Multiple groups without normal distribution were compared using the Kruskal-Wallis test with Bonferroni correction. A $p$ value of $<0.05$ was considered statistically significant.

\section{RESULTS}

Both groups were compared in terms of demographic and operative variables (Table 1). The patient group was significantly older $(65.4 \pm 6.8$ years vs. $57.5 \pm 8.5$ years, respectively; $\mathrm{p}<0.001)$ and had a higher number of cases with carotid artery stenosis ( $25.7 \%$ vs. $7.9 \%$, respectively; $\mathrm{p}=0.011$ ). Postoperative 24-h and 120-h GFRs were lower in the patient group ( $\mathrm{p}=0.010, \mathrm{p}=0.002$, respectively).

Of all 124 patients, there were four (3.2\%) ischemic events: one patient had an ischemic stroke and three patients had transient ischemic attacks. There was no significant difference between the groups in terms of major neurological complications.

Patients with and without carotid artery stenosis were compared for their ascending aorta, aortic arch, and total aortic CSs (Table 2). The aortic arch CS was higher in the patients with carotid artery stenosis $(\mathrm{p}=0.042)$, while the ascending aorta and total aortic CS were not significantly different $(p=0.909, p=0.089$, respectively).

Although the number of the patients with decreased SMMSE scores in the patient group (48.6\%) was higher than the control group (34.8\%), this result was not statistically significant. The SMMSE score decline and percentage decline were compared between the groups, yielding no significant difference (Table 3 ).

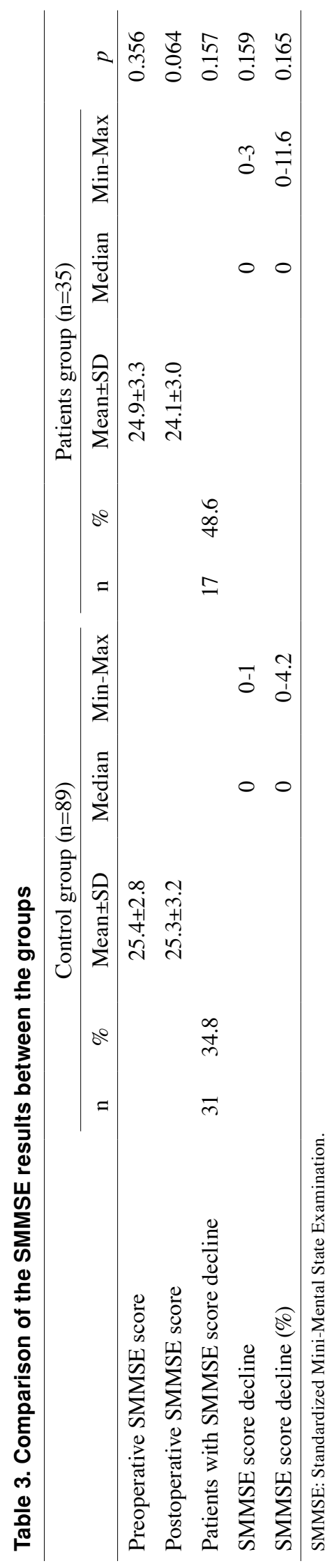


Table 4. Evaluation of the SMMSE Score decline between groups

\begin{tabular}{|c|c|c|c|c|c|c|c|}
\hline & \multirow{2}{*}{\multicolumn{2}{|c|}{ Control group $(n=89)$}} & \multicolumn{4}{|c|}{ Patients group $(n=35)$} & \multirow{3}{*}{$p$} \\
\hline & & & \multicolumn{2}{|c|}{$\begin{array}{c}\text { Low aortic arch } \mathrm{CS}(\mathrm{n}=28) \\
(<2,250 \mathrm{AU})\end{array}$} & \multicolumn{2}{|c|}{$\begin{array}{c}\text { High aortic arch } \mathrm{CS}(\mathrm{n}=7) \\
(\geq 2,250 \mathrm{AU})\end{array}$} & \\
\hline & Median & Min-Max & Median & Min-Max & Median & Min-Max & \\
\hline SMMSE score decline & 0.0 & $-1.0-0.0$ & 0.0 & $-1.0-0.0$ & -3.00 & $-5.00--1.50$ & 0.026 \\
\hline SMMSE score decline (\%) & 0.0 & $-4.17-0.0$ & 0.0 & $-4.55-0.0$ & -12.00 & $-17.59--5.56$ & 0.029 \\
\hline
\end{tabular}

CS: Calcium score; AU: Agatston unit; SMMSE: Standardized Mini-Mental State Examination.

Changes in the SMMSE scores were further compared between the control group, patients with low aortic arch CS, and high aortic arch CS. The patients with high aortic arch CSs showed a decline in their postoperative SMMSE scores $(\mathrm{p}=0.026)$ (Table 4). Post-hoc analysis with Bonferroni correction
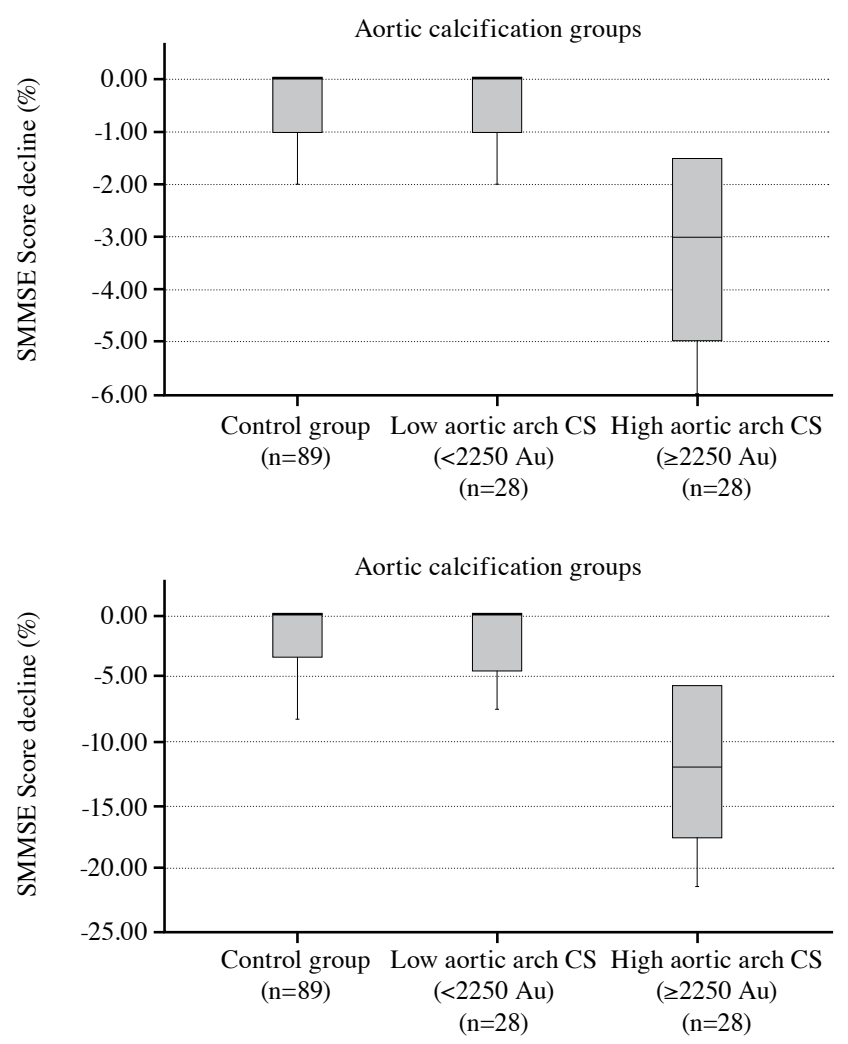

Figure 2. Comparison of SMMSE score decline and percentage decline between groups. $\mathrm{P}$ values for SMMSE score decline and SMMSE score decline (\%) respectively; High aortic arch CS group had a greater decline than the control group $(\mathrm{p}=0.007$ and $\mathrm{p}=0.008)$ and the low aortic arch CS group $(\mathrm{p}=0.028$ and $\mathrm{p}=0.035)$, and low aortic arch CS group had no statistically significant decline than the control group $(\mathrm{p}=0.570$ and $\mathrm{p}=0.508)$. CS: Calcium score; AU: Agatston unit, SMMSE: Standardized Mini-Mental State Examination. revealed the difference between high aortic arch CS and control groups to be significant for both absolute decline and percentage decline in the SMMSE scores (Figure 2). However, there was no significant decline in the SMMSE scores according to the ascending aorta CS and total aortic CSs.

\section{DISCUSSION}

Aortic calcification detectable on $\mathrm{CR}$ has been shown to be associated with DM, renal disease, and adverse cardiovascular events, although the association of AC detectable on CR for POND in CABG patients has not been studied, yet. ${ }^{[7,14]}$ In the present study, we investigated the association between AC detected on preoperative $\mathrm{CR}$ and $\mathrm{POND}$ in patients undergoing elective CABG. Our study results showed a decline in the postoperative neurological function as assessed by SMMSE with an increased calcification on aortic arch that was detectable on CR.

Computed tomography is an easy and effective diagnostic tool to define the extension of the $\mathrm{AC}$ detected on CR. Determination of the ascending aorta and aortic arch CS values is possible with non-contrast CT angiography. High aortic CS has been found to be associated with DM, and adverse cardiovascular events postoperatively. ${ }^{[15,16]}$ The most difficult decision for us was determining the cut-off value for the high aortic CS distinction. Although there was a previously described cut-off value for aortic valve CS (high/low) in previous guidelines, there was no defined cutoff value for ascending aorta and aortic arch CS in the literature. ${ }^{[17]}$ We defined the value of $\geq 2,250$ $\mathrm{AU}$ for aortic CS in our study, which was found to be associated with poor clinical outcomes in aortic valve replacement patients. ${ }^{[9]}$ In this study, the aortic arch CS was found to be related to carotid artery stenosis in the patient group. This can be explained by the proximity of the carotid artery to the aortic arch, rather than the ascending aorta. Carotid artery stenosis was also 3.2 times higher in our patient group. 
In previous studies, advanced age and carotid artery intima-media thickness was also found to be related to $\mathrm{AC}$ on $\mathrm{CR} \cdot{ }^{[7,14]}$ Therefore, it seems to be reasonable to screen patients with $\mathrm{AC}$ for carotid stenosis, if not routinely performed before CABG.

Aortic cross-clamp time, $\mathrm{CPB}$ time, AF, and blood transfusions are the other factors which are thought to be implicated in the etiology of POND..$^{[18-23]}$ Operative strategies including single aortic clamp and care against aortic manipulation may reduce the risk for POND by decreasing microembolism. No-touch technique for proximal anastomoses, offpump surgery, and hybrid procedures can be reliable alternatives in patients with $\mathrm{AC}$ to prevent POND and overall mortality. ${ }^{[24]}$ These strategies may be more important for patients with preoperatively detected AC to prevent POND and CVA.

Patients with AC may be also susceptible to other non-neurological morbidities after cardiac surgery. Aortic calcification in thoracic aorta is associated with left ventricular hypertrophy. ${ }^{[9]}$ According to Korkmaz et al., ${ }^{[25]} \mathrm{AC}$ detected on $\mathrm{CR}$ was an independent predictor of complex coronary artery lesions. In addition, AC in the descending aorta was found to be associated with acute kidney injury and in-hospital mortality ${ }^{[26]}$ In our patients with $\mathrm{AC}$, postoperative GFR was lower, despite similar preoperative renal functions and comorbidities.

The relationship between delirium and POND after CABG has been demonstrated by Saczynski et al., ${ }^{[27]}$ and it is known that prolonged ICU stay is associated with delirium. ${ }^{[27-29]}$ In our study, daily CAM-ICU tests were conducted during the ICU stay, and no significant difference was found between the groups in terms of early or late delirium. Delirium has multifactorial causes and whether $\mathrm{AC}$ is a risk factor requires other dedicated studies that focus on this relationship.

One of the main limitations to the present study is that our sample size is relatively small due to the highly selective exclusion criteria. Although the rate of $\mathrm{AC}$ in $\mathrm{CABG}$ patients resembles our study population, the amount of the groups is statistically difficult to compare. In addition, the patient group was significantly older which may have led to a bias. On the other hand, advanced age, carotid artery stenosis, and $\mathrm{AC}$ are relevant and expected to be found to be concomitant conditions. Further randomized-controlled studies are needed to reveal the exact association of $\mathrm{AC}$ and neurocognitive impairment. A challenge in defining POND after
CABG is the tests used for this purpose which all have their own drawbacks. In this study, we used the SMMSE for neurocognitive assessment, despite its disadvantages such as the ceiling effect, since it is a simple test that is easy to conduct and is widely used in the evaluation of delirium and dementia. Finally, since this study is an observational study, the surgeons performed their operations with their routine technique. Further well-designed studies with a standardized clamp technique and proximal anastomosis may produce more accurate results for neurocognitive impairment. Nevertheless, to the best of our knowledge, this is the first study to investigate the relationship between AC detectable on CR and neurocognitive outcomes in CABG patients and we believe it provides additional contribution to the body of knowledge on this topic.

In conclusion, neurocognitive impairment after coronary artery bypass grafting may be associated with aortic calcifications detected on chest radiography. The patients with higher aortic arch calcium scores on computed tomography may have worse neurocognitive outcomes. It would be wise to perform computed tomography in patients with aortic calcifications as evidenced by chest radiography to evaluate the extent of calcification and neurocognitive outcomes.

\section{Declaration of conflicting interests}

The authors declared no conflicts of interest with respect to the authorship and/or publication of this article.

\section{Funding}

The authors received no financial support for the research and/or authorship of this article.

\section{REFERENCES}

1. Hammon JW, Stump DA, Butterworth JF, Moody DM, Rorie $\mathrm{K}$, Deal DD, et al. Coronary artery bypass grafting with single cross-clamp results in fewer persistent neuropsychological deficits than multiple clamp or off-pump coronary artery bypass grafting. Ann Thorac Surg 2007;84:1174-8.

2. Alexander JH, Smith PK. Coronary-artery bypass grafting. $N$ Engl J Med 2016;374:1954-64.

3. Özgök A, Ulus AT, Karadeniz Ü, Demir A, Kazancı D, Özyalçın S, et al. Does uncontrolled diabetes mellitus affect cerebral hemodynamics in heart surgery? Turk Gogus Kalp Dama 2020;28:84-91.

4. Yuan SM, Lin H. Postoperative cognitive dysfunction after coronary artery bypass grafting. Braz J Cardiovasc Surg 2019;34:76-84.

5. Andersen ND, Hart SA, Devendra GP, Kim ESH, Johnston DR, Schroder JN, et al. Atheromatous disease of the aorta and perioperative stroke. J Thorac Cardiovasc Surg 2018;155:508-16. 
6. Buz S, Pasic M, Unbehaun A, Drews T, Dreysse S, Kukucka $\mathrm{M}$, et al. Trans-apical aortic valve implantation in patients with severe calcification of the ascending aorta. Eur J Cardiothorac Surg 2011;40:463-8.

7. Hashimoto H, Iijima K, Hashimoto M, Son BK, Ota H, Ogawa $\mathrm{S}$, et al. Validity and usefulness of aortic arch calcification in chest X-ray. J Atheroscler Thromb 2009;16:256-64.

8. Agatston AS, Janowitz WR, Hildner FJ, Zusmer NR, Viamonte M Jr, Detrano R. Quantification of coronary artery calcium using ultrafast computed tomography. J Am Coll Cardiol 1990;15:827-32.

9. Cho IJ, Chang HJ, Heo R, Kim IC, Sung JM, Chang BC, et al. Association of thoracic aorta calcium score with left ventricular hypertrophy and clinical outcomes in patients with severe aortic stenosis after aortic valve replacement. Ann Thorac Surg 2017;103:74-81.

10. Ely EW, Margolin R, Francis J, May L, Truman B, Dittus R, et al. Evaluation of delirium in critically ill patients: Validation of the Confusion Assessment Method for the Intensive Care Unit (CAM-ICU). Crit Care Med 2001;29:1370-9.

11. Aypar Ü, Kanbak M, Yorgancı K, Özdemir H, Akıncı SB, Çelikcan A, et al. Yoğun bakım ünitesinde konfüzyon değerlendirme ölçeğinin geçerlik güvenilirlik çalışması. Türk Anestezi ve Reanimasyon Dergisi 2005;33:333-41.

12. Khadka J, McAlinden C, Pesudovs K. Cognitive trajectories after postoperative delirium. N Engl J Med 2012;367:1164.

13. Güngen C, Ertan T, Eker E, Yaşar R, Engin F. Standardize Mini Mental Test'in Türk toplumunda hafif demans tanisinda geçerlik ve güvenilirliği. Türk Psikiyatri Dergisi 2002;13:273-81.

14. Iijima K, Hashimoto H, Hashimoto M, Son BK, Ota H, Ogawa S, et al. Aortic arch calcification detectable on chest $\mathrm{X}$-ray is a strong independent predictor of cardiovascular events beyond traditional risk factors. Atherosclerosis 2010;210:137-44.

15. Eisen A, Tenenbaum A, Koren-Morag N, Tanne D, Shemesh J, Imazio M, et al. Calcification of the thoracic aorta as detected by spiral computed tomography among stable angina pectoris patients: Association with cardiovascular events and death. Circulation 2008;118:1328-34.

16. Churchill TW, Rasania SP, Rafeek H, Mulvey CK, Terembula $\mathrm{K}$, Ferrari V, et al. Ascending and descending thoracic aorta calcification in type 2 diabetes mellitus. J Cardiovasc Comput Tomogr 2015;9:373-81.

17. Baumgartner H, Falk V, Bax JJ, De Bonis M, Hamm C, Holm PJ, et al. 2017 ESC/EACTS Guidelines for the management of valvular heart disease. Eur Heart $\mathbf{J}$ 2017;38:2739-91.
18. Salis S, Mazzanti VV, Merli G, Salvi L, Tedesco CC, Veglia $\mathrm{F}$, et al. Cardiopulmonary bypass duration is an independent predictor of morbidity and mortality after cardiac surgery. $\mathrm{J}$ Cardiothorac Vasc Anesth 2008;22:814-22.

19. Goto T, Maekawa K. Cerebral dysfunction after coronary artery bypass surgery. J Anesth 2014;28:242-8.

20. Stanley TO, Mackensen GB, Grocott HP, White WD, Blumenthal JA, Laskowitz DT, et al. The impact of postoperative atrial fibrillation on neurocognitive outcome after coronary artery bypass graft surgery. Anesth Analg 2002;94:290-5.

21. Hogue CW, Fucetola R, Hershey T, Freedland K, DávilaRomán VG, Goate AM, et al. Risk factors for neurocognitive dysfunction after cardiac surgery in postmenopausal women. Ann Thorac Surg 2008;86:511-6.

22. Kapoor MC. Neurological dysfunction after cardiac surgery and cardiac intensive care admission: A narrative review part 1: The problem; nomenclature; delirium and postoperative neurocognitive disorder; and the role of cardiac surgery and anesthesia. Ann Card Anaesth 2020;23:383-90.

23. Kapoor MC. Neurological dysfunction after cardiac surgery and cardiac intensive care admission: A narrative review part 2: Cognitive dysfunction after critical illness; potential contributors in surgery and intensive care; pathogenesis; and therapies to prevent/treat perioperative neurological dysfunction. Ann Card Anaesth 2020;23:391-400.

24. Zubarevich A, Kadyraliev B, Arutyunyan V, Chragyan V, Askadinov M, Sozkov A, et al. On-pump versus off-pump coronary artery bypass surgery for multi-vessel coronary revascularization. J Thorac Dis 2020;12:5639-46.

25. Korkmaz L, Adar A, Ata Korkmaz A, Erkan H, A ğaç MT, Acar Z, et al. Aortic knob calcification and coronary artery lesion complexity in non-ST-segment elevation acute coronary syndrome patients. Turk Kardiyol Dern Ars 2012;40:606-11.

26. Nowak-Machen M, Rawn JD, Shekar PS, Mitani A, Tuli S, Bingold TM, et al. Descending aortic calcification increases renal dysfunction and in-hospital mortality in cardiac surgery patients with intraaortic balloon pump counterpulsation placed perioperatively: A case control study. Crit Care 2012;16:R17.

27. Saczynski JS, Marcantonio ER, Quach L, Fong TG, Gross A, Inouye SK, et al. Cognitive trajectories after postoperative delirium. N Engl J Med 2012;367:30-9.

28. Andrejaitiene J, Sirvinskas E. Early post-cardiac surgery delirium risk factors. Perfusion 2012;27:105-12.

29. Şaşkın H, Özcan KS, Düzyol Ç, Maçika H, Aksoy R, İdiz M. An easily overlooked clinical phenomenon after coronary artery bypass graft surgery: Postoperative delirium. Turk Gogus Kalp Dama 2016;24:248-57. 